\title{
Improve the Nutritive Value of Produced Cake by Replacement Wheat Flour with Pearl Millet Flour

\author{
El Tanahy, H. H. ${ }^{1}$; Sharoba, A.M. ${ }^{1}$; Ghazal, G.A. ${ }^{1}$; Abd Elmola, E.M. ${ }^{2}$ and Zamzam, E.H. ${ }^{1,3}$ \\ ${ }^{1}$ Department of Food Technology, Faculty of Agriculture, Benha University, Egypt. \\ ${ }^{2}$ Arab Academy for Science, Technology \& Maritime Transport, Arab League.
} \\ ${ }^{3}$ School Feeding Project, Food Technology Institute, Agricultural Research Center, Egypt. \\ Corresponding Author: ashraf sharoba@yahoo.com
}

\begin{abstract}
Bakeries occupy an important position in human nutrition locally and globally. The result of gap between production and consumption for wheat, the government are imported wheat from different countries. Millets are widely grown in the semiarid tropics of Africa and Asia. It serves as a major food component in various traditional foods such as bread, porridges and snack foods. In this study replacement wheat flour (72\% ext.) with pearl millet flour for manufacture the blends of cake. (10\% pearl millet flour $+90 \%$ wheat flour, $20 \%$ pearl millet flour $+80 \%$ wheat flour, $30 \%$ pearl millet flour $+70 \%$ wheat flour and $100 \%$ pearl millet flour). The chemical composition, rheological properties, textures, staling, microbiological examination and sensory properties of produced cake and during the storage period of 8 days at $25 \pm 1{ }^{\circ} \mathrm{C}$ were done. The results showed that a clear and noticeable improvement of all characteristics of produced cake, which was the increase of ash, protein, fiber, fat and carbohydrate compared to the control sample. Therefore, the study recommended that using the pearl millet flour for the manufacture of bakery products.
\end{abstract}

Keywords: Millet- chemical composition- rheological properties- microbiological examination - cake

\section{Introduction}

Cakes are an important bakery product category alongside breads. Cakes can be defined as being aerated and chemically leavened bakery products (Kahraman et al., 2008) .Cakes are the most consumed bakery product attributable to interesting items and are constantly utilized as a part of celebrations and also in happy festivals (Hafez et al., 2012 and Zhang et al., 2012).

Bakery products are extensively consumed and therefore particular requirements for their quality characteristics have been established. Especially for cake, shape, color and texture are important for consumers. Shelf-life of bakery products is mainly limited by staling. Staling is a process of chemical and physical changes including moisture redistribution, drying, starch retrogradation, increased firmness and fragility, as well as loss of aroma and flavor (Amigo et al., 2016).

The flour which is used to make cakes are generally derived from wheat grain with lower protein content compared with the wheat flour used to make bread. This flour is responsible for the unique texture and appearance properties of cakes. The baking properties of flour into cakes have been investigated to some extent in the past and these researches have mainly focused on exploring the role of flour components on the baking properties of cake either for their starch fractions or their gluten forming fractions (Wilderjans et al., 2008).

Rajiv et al. (2011) studied the effect of replacement of wheat flour with $0,20,40,60,80$ and $100 \%$ finger millet to make cake incorporation of finger millet flour, which is a good source of minerals, increases the nutritive value of cake and also it is a value addition to the finger millet.
Millet grains account for about one sixth of the total food grain production hold an important place in the food grain economy of India. On the other hand, India is the largest producer of millet grains, producing about $33-37 \%$ of a total of 28 million tones of the world production. Finger millet constituted about 81 per cent of the minor millets produced in India and the rest by kodo millet, foxtail millet and little millet, (Pradhan et al., 2010). Millet contains about $65-75 \%$ carbohydrates, 5 - 10\% protein and $15-20 \%$ dietary fiber (Chethan and Malleshi 2007). It is a good source of minerals (2.5$3.5 \%$ ) especially calcium, iron and phosphorous (Subba and Muralikrishna 2001). Millet is considere to have the highest calcium content of cereal grains, at about $344 \mathrm{mg} / 100 \mathrm{~g}$. There are many polyphenols found in millet, and in combination with the dietary fiber, millet is known to have several health benefits such as antioxidant, antimicrobial and hypocholesterolaemic properties (Devi et al., 2011). Furthermore, millet is gluten free.

Pearl millet may be used as a low cost and nutritional ingredient in infant foods and functional food products such as beverages, custard and soup mixes etc. Due to its gluten free nature, pearl millet can be successfully used in breads, cookies or breakfast items. Utilization of pearl millet flour in food product preparation significantly improved the nutritional quality by contributing to higher protein, ash and mineral content (iron, calcium and phosphorus). Products prepared from the pearl millet flour had similar sensory profiles however they differed significantly from traditional products in key attributes such as taste, aroma, and overall acceptability indicating that products prepared from pearl millet were highly acceptable Florence Suma (2012). This study has shown a potential use of 
inexpensive and underutilized pearl milled flour in the preparation of cake.

\section{Materials and Methods:}

\section{Materials}

Wheat flour (72\% extraction): was obtained from local market, Zifta, Algarbia, Egypt.

Baking Ingredients: milk, salt, sugar, eggs, oil, vanilla and baking powder were purchased from local market, Zifta, Algarbia, Egypt.

Pearl millet (Pennisetum glaucum): was purchased from local market, Zifta, Algarbia, Egypt.
Methods

Preparation of cake:

Cake was prepared by mixing wheat flour and pearl millet flour, oil, butter, sugar, fresh whole egg, baking powder, milk, vanilla as shown in Table (1). The mixture was whipped until got smooth. Then baked in an electric oven (Mac.pan, Italy) at $200 \pm 5^{\circ} \mathrm{C}$ about the dough transferred to greased pan and was baked for $25 \mathrm{~min}$. then was cooled at room temperature AACC (2002) and Sharoba et al. (2013).

Table 1. Replacement pearl millet flour with wheat flour (72\% ext.) in production cakes.

\begin{tabular}{ll}
\hline Treatment No. & Blends \\
\hline Control (1) & $\mathbf{1 0 0 \%}$ wheat flour \\
E1 & $\mathbf{9 0 \%}$ wheat flour+ $10 \%$ pearl millet flour \\
E2 & $\mathbf{8 0 \%}$ wheat flour+ $20 \%$ pearl millet flour \\
E3 & $\mathbf{7 0 \%}$ wheat flour+ $30 \%$ pearl millet flour \\
Control (2) & $\mathbf{1 0 0 \%}$ pearl flour
\end{tabular}

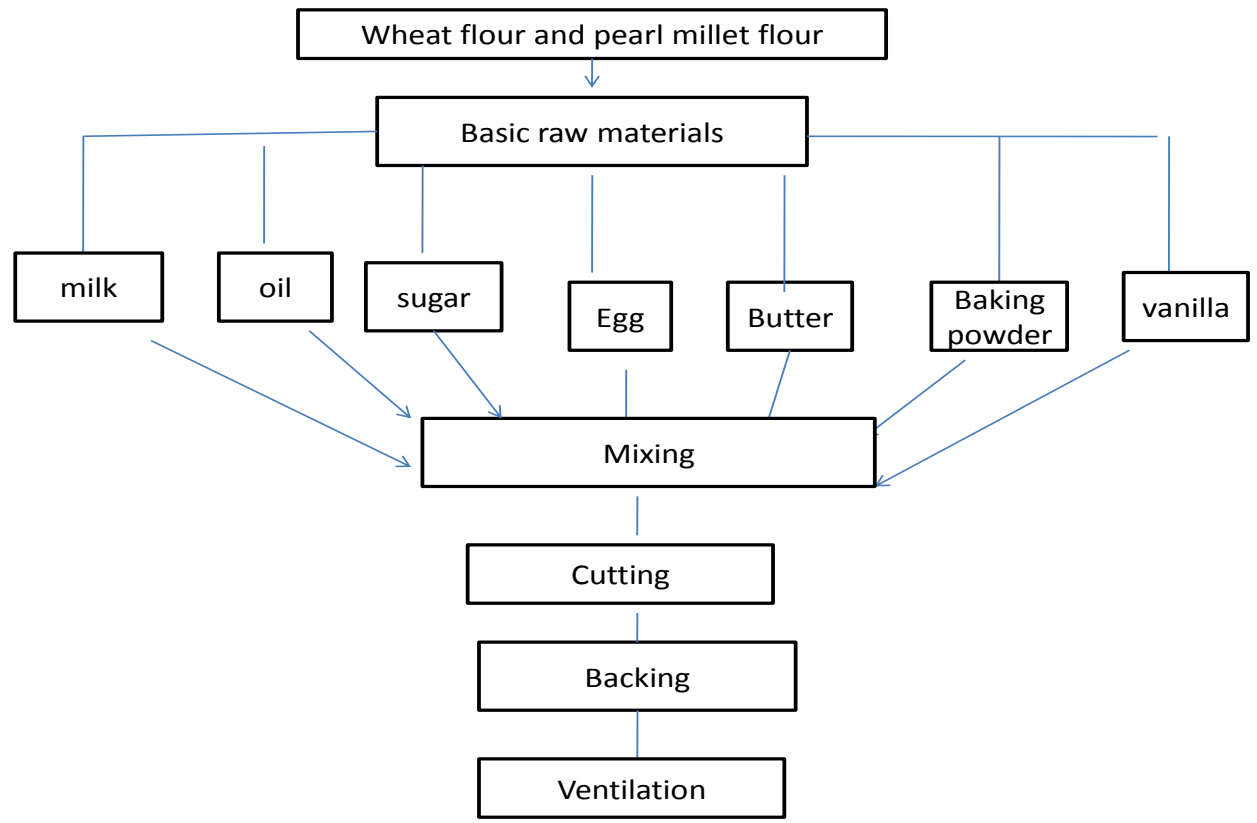

Fig. (1): Processing of Cakes using different levels from pearl millet, and mixing to wheat flour (72\% ext).

\section{Chemical analysis:}

Moisture, protein, ash, crude fiber, ether extract, starch and reducing and non reducing sugars contents were determined according to the methods described in AOAC (2016). Total carbohydrates were calculated by difference.

Energy Value $=(\%$ Protein $\times 4)+(\%$ Carbohydrate $\times 4)+(\%$ Fat $\times 9)$.

\section{Rheological properties:}

\section{Farinograph test:}

The farinograph (877563 Brabender farinograph germany HZ 50) was used to study the hydration and mixing characteristics of the dough according to AACC (2002).

Extensograph test:

Extensograph test was carried out according to the method described in the AACC (2002) using an extensograph type: 4821384 (Brabender Extensograph Germany HZ 50).

\section{Mixolab test:}

Mixolab analysis was carried out at the water absorption level determined by the consistograph following the AACC (2000). 
Physical analysis of cakes:

Texture measurements (mechanical properties) of cakes:

Mechanical properties of cake and stored at room temperature $\left(25 \pm 1{ }^{\circ} \mathrm{C}\right)$ for 8 days mechanical properties measured at $0,2,4,6$ and 8 days were performed with a Universal Testing Machine Cometech (B type, Taiwan) operated at a crosshead speed of $100 \mathrm{~mm}$ min-1. The shear force needed to cut the sample $(5 \mathrm{~cm}$ diameter) with a flat ended probe $(2.5 \mathrm{~mm}$ thickness) was registered. All measurements were performed at ambient temperature $\left(25 \pm 5^{\circ} \mathrm{C}\right)$ according to Caballero et al. (2007).

Microbiological examination:

Preparation of samples for microbiological examination:

Ten grams of each sample were homogenized with $90 \mathrm{ml}$ of sterile saline solution $(9 \mathrm{~g} \mathrm{NaCL} / \mathrm{L}$ distilled water). The suspension was shacked by shaker for 5 minutes to give 0.1 dilutions. Then different dilutions $\left(1: 10^{-1}\right.$ to $\left.1: 10^{-6}\right)$ were prepared to be used for microbiological examination according to (U.S. Food and Drug Administration, 2001).

Total viable bacterial count, Moulds and yeasts and Coliform bacteria count:

Total viable bacterial count, Moulds and yeasts and Coliform bacteria count were counted according to the method described by the methodology of (APHA, 1992).

Sensory evaluation of cakes:
Produced cake was evaluated according to the method described by AACC (2002) A group of graduate students in Food Technology Department, Faculty of Agriculture, Moshtohor, Benha University. Cake samples were left to cool at room temperature for $1 \mathrm{hr}$. after baking. Then cake was cut with a sharp knife and subjected to panel test general appearance (10), drumming (10), crust color (10), crumb color (10), taste (10), thawing in the mouth (10), cohesion (10) height (10), textures (10), odor (10) and overall acceptability was calculated (100).

\section{Statistical analysis:}

ANOVA was applied on data of organoleptic evaluation of produced cake which were treated as data for complete randomization design by using Microsoft Excel 2010 least significant difference (L.S.D.) was calculated at 0.05 level of significance according to Levine et al. (1999).

\section{Results and Discussion:}

\section{Chemical composition of pearl millet flour:}

Chemical composition of pearl millet flour are shown in Table (2). These results show that medium pearl millet flour contained are $11.21 \%$ moisture, $11.07 \%$ protein, $5.88 \%$ fat, $1.39 \%$ fiber and $1.48 \%$ ash and $68.96 \%$ total carbohydrates respectively.

These results are nearly in agreement with those reported by Florence Suma (2012). All the results indicated that the pearl millet flour which is agood source protein and fat increases the nutritive value of cake.

Table 2. Chemical composition of both pearl millet flour and wheat flour.

\begin{tabular}{lccccccc}
\hline Material & Moisture & Fat & Protein & Ash & $\begin{array}{c}\text { Crude } \\
\text { fiber }\end{array}$ & $\begin{array}{c}\text { Available } \\
\text { carbohydrate }\end{array}$ & $\begin{array}{c}\text { Energ } \\
\text { y }\end{array}$ \\
\hline Pearl millet flour & $\mathbf{1 1 . 2 1}$ & $\mathbf{5 . 8 8}$ & $\mathbf{1 1 . 0 7}$ & $\mathbf{1 . 4 8}$ & $\mathbf{1 . 3 9}$ & $\mathbf{8 0 . 1 8}$ & $\mathbf{4 2 0 . 4 4}$ \\
Wheat flour 72\% & $\mathbf{1 3 . 9 8}$ & $\mathbf{1 . 1 7}$ & $\mathbf{1 0 . 8 8}$ & $\mathbf{0 . 5 1}$ & $\mathbf{0 . 0 5}$ & $\mathbf{8 7 . 3 9}$ & $\mathbf{4 0 3 . 6 1}$ \\
\hline
\end{tabular}

Rheological properties of pearl millet flour:

Concerning dough rheology, it is well known that the farinograph parameters indicate the most important properties in this dough. The rheological properties of dough have an immediate impact on functionality of dough; therefore, it may be used as reliable predictors of its behavior during the baking process as well as the quality of the final product.

Effect of replacement wheat flour with pearl millet flour on rheological properties:

Farinograph parameters:

The farinograph properties of replacement wheat flour with pearl millet flour containing different levels of pearl millet flour are shown in Table (3).Water absorption of the pearl millet flour sample was the highest compared with other treatments being $(65 \%)$, while it was for the control sample 59.1 $\%$. It could be observed that with increasing the amount of pearl millet flour, there was a decrease in the water absorption. These results are in agreement with those reported by Lorenz and Dilsaver (1980). The decrease in water absorption and dough development time of the finger millet flour blend is attributed to the lowering of the gluten content in the blends as a result of incorporation of the millet flour that is gluten free. (Aprodu and Banu, 2014 and Maktouf et al., 2016) reported that increasing the level of millet flour to wheat flour caused to decrease of the development time in dough formulations. Gavurnikova et al. (2011).

Data obtained in Table (3) indicated that the replacement of wheat flour with pearl millet flour lowered the stability time of dough. The highest time observed in blend sample that contained $10 \%$ pearl millet flour. Increasing the level of pearl millet flour decreased the dough stability time as comparing with the control sample. 
Table 3. Farinograph properties of pearl millet flour and replacement wheat flour with pearl millet flour.

\begin{tabular}{llllll}
\hline $\begin{array}{l}\text { Sample } \\
\text { (No.) }\end{array}$ & $\begin{array}{l}\text { Water } \\
\text { Absorption \% }\end{array}$ & $\begin{array}{l}\text { Arrival time } \\
(\text { min) }\end{array}$ & $\begin{array}{l}\text { Dough } \\
\text { Development } \\
(\text { min) }\end{array}$ & $\begin{array}{l}\text { Stability } \\
\text { time } \\
(\text { min) }\end{array}$ & $\begin{array}{l}\text { Degree of } \\
\text { softening (B.U) }\end{array}$ \\
\hline Control & 59.1 & 1.5 & 2 & 13 & 30 \\
E1 & 58 & 1.0 & 1.5 & 12.5 & 20 \\
E2 & 56.5 & 1 & 1.5 & 7.5 & 90 \\
E3 & 54.8 & 2 & 2.5 & 7.5 & 90 \\
E4 & 65 & 1.5 & 2 & 2 & 0 \\
\hline
\end{tabular}

E1: $90 \%$ wheat flour $+10 \%$ pearl millet flour

E3: $70 \%$ wheat flour $+30 \%$ pearl millet flour

\section{Extensograph parameters:}

The results in Table (4) shows effect of replacement wheat flour with pearl millet flour at different levels to mean flour on extensograph parameters. Data indicated that resistance to control sample flexibility was 390 B.U. There are changes in elasticity with the effect of replacement wheat flour with pearl millet flour intermediate flour. The elasticity was gradually decreased with the addition of pearl millet flour increased flexibility to 300 B.U. It decreased from the addition of pearl millet flour as it became180 B.U.

The extensibility (E) showed a value of $75 \mathrm{~mm}$ for control (wheat flour $72 \%$ ext.). The addition of $10 \%$ pearl millet flour $+90 \%$ wheat flour reached to
E2: $80 \%$ wheat flour $+20 \%$ pearl millet flour

E4: $100 \%$ pearl millet flour

Table 4. Extensograph properties of pearl millet flour and replacement of wheat flour with pearl millet flour.

\begin{tabular}{lllll}
\hline Blends & Elasticity $($ B.U) & Extensibility $(\mathbf{m m})$ & Proportional Number & Energy $($ Cm2 $)$ \\
\hline Control & 390 & 75 & $\mathbf{5 . 2 0}$ & $\mathbf{5 2}$ \\
E1 & 180 & 135 & 1.33 & 43 \\
E2 & 260 & 95 & 2.47 & 42 \\
E3 & 200 & 100 & 2.00 & 33 \\
E4 & 90 & 35 & 2.57 & 6 \\
\hline
\end{tabular}

E1: $90 \%$ wheat flour $+10 \%$ pearl millet flour $\quad$ E2: $80 \%$ wheat flour $+20 \%$ pearl millet flour

E3: $70 \%$ wheat flour $+30 \%$ pearl millet flour $\quad$ E4: $100 \%$ pearl millet flour

Effect of replacement wheat flour with pearl millet flour on Mixolab parameters:

Date in Table (5) shows the effect of replacement wheat flour with pearl millet flour at different levels. The mixolab curve is divided into five different stages, in the first stage (C1). The dough development values show a rise in the flour treatment with enzymes, which decreased slightly in the second phase $(\mathrm{C} 2)$ and ranged from 0.437 to $0.508 \mathrm{Nm}$ compared with the torque value in control sample is $0.552 \mathrm{Nm}$ The third phase (C3), which is called starch gluten at this stage and the product during heating from $1.98 \mathrm{Nm}$ in the control sample to $1.877 \mathrm{Nm}$ in the sample of (E1).In the first phase (C1), the effect replacement wheat flour with pearl millet flour was found on the values of dough development and Stage three (C3) in control sample and decreased in all samples when increased the value of pearl millet flour in the samples These results are in agreement with those reported by Sharma et al. (2017). the highest value being $135 \mathrm{~mm}$. The relative number was dependent on the results of (R) and (E). Therefore, a similar relationship was found of the relative number $(\mathrm{R} / \mathrm{E})$ of the dough. The data in Table (4) also showed that the additions decreased the relative number ( $\mathrm{R} / \mathrm{E}$ ) as compared with the sample control. Data in Table (4) showed that the effect of replacement wheat flour with pearl millet flour on Elasticity, extensibility, (E), the extension resistance $(\mathrm{R})$ and the ratio between them as well as the energy. In terms of energy, control resulted in the highest value (52), while the pearl millet flour sample was the lowest value (6).
The fourth phase (C4) of $1.788 \mathrm{Nm}$ in control sample and decreased in samples added to pearl millet flour compared to a control sample ranging from 1.735 to $1.137 \mathrm{Nm}$. the amount of pearl millet flour in the samples increases the amylase activity decreases leading to lower breakdown and hence viscosity is increased. These results are in agreement with those reported by Goswami et al. (2015).

The effect of replacement wheat flour with pearl millet flour to improvers the nutritive value of cake product:

In this part of the effect of replacement wheat flour with pearl millet flour by add $10 \%$ pearl millet flour $+90 \%$ wheat flour, $20 \%$ pearl millet flour $+80 \%$ wheat flour, $30 \%$ pearl millet flour $+70 \%$ wheat flour and $100 \%$ pearl millet to make cake and all the quality characteristics chemical, microbiological, and sensory of cake and finally measure freshness of the product were studied. 
Effect of storage period at room temperature (25 $\pm 1 \square$ C) on chemical composition of produced cake by replacement of wheat flour with pearl millet flour:

Chemical composition is great importance in judging the quality of the cake product. The moisture, ash, protein, fat, fiber and available carbohydrate contents of cake made by replacement wheat flour with pearl millet flour were determined. Data in Table (6) show the moisture content in control sample was higher than that of E1, E2, E3 and E4 samples, due to its retention of water. These results are in agreement with those reported by Rajive et al. (2011).

Table 5. Effect of replacement wheat flour with pearl millet flour on Mixolab parameters.

\begin{tabular}{|c|c|c|c|c|}
\hline Parameters & Control & E1 & E2 & E3 \\
\hline Stability & 9.55 & 9.77 & 10.00 & 10.20 \\
\hline Absorption & 6 & 5 & 3 & 1 \\
\hline Mixing & 5 & 5 & 4 & 5 \\
\hline Gluten+ & 5 & 4 & 2 & 3 \\
\hline Viscosity & 7 & 7 & 6 & 7 \\
\hline Amylase & 8 & 7 & 5 & 7 \\
\hline Retrogradation & 7 & 5 & 3 & 4 \\
\hline C1(Nm) & 1.137 & 1.12 & 1.087 & 1.084 \\
\hline $\mathrm{C} 2(\mathrm{Nm})$ & 0.552 & 0.508 & 0.438 & 0.437 \\
\hline $\mathrm{C3}(\mathrm{Nm})$ & 1.89 & 1.877 & 1.752 & 1.823 \\
\hline $\mathrm{C4}(\mathrm{Nm})$ & 1.788 & 1.735 & 1.502 & 1.606 \\
\hline C5 $(\mathrm{Nm})$ & 2.702 & 2.363 & 1.833 & 2.121 \\
\hline
\end{tabular}

E1: $90 \%$ wheat flour $+10 \%$ pearl millet flour

E3: $70 \%$ wheat flour $+30 \%$ pearl millet flour

E2: $80 \%$ wheat flour $+20 \%$ pearl millet flour

Table 6. Effect of storage period at room temperature $(25 \pm 1 \square \mathrm{C})$ on chemical composition of produced cake by replacement wheat flour with pearl millet flour during storage at $25 \pm 1 \square \mathrm{C}$ for 8 days.

\begin{tabular}{|c|c|c|c|c|c|c|}
\hline \multirow{2}{*}{$\begin{array}{l}\text { Chemical } \\
\text { Attributes }\end{array}$} & \multicolumn{6}{|c|}{ Storage periods (days) } \\
\hline & Blends & zero & 2 & 4 & 6 & 8 \\
\hline \multirow[t]{5}{*}{ Moisture (\%) } & Control & 24.15 & 23.56 & 21.26 & 19.89 & $\mathbf{1 7 . 3 4}$ \\
\hline & E1 & 23.51 & 21.70 & 19.74 & 18.54 & 16.99 \\
\hline & $\mathbf{E 2}$ & 22.86 & 20.91 & 19.56 & 18.24 & 16.44 \\
\hline & E3 & 22.21 & 19.99 & 18.55 & 17.13 & 16.00 \\
\hline & $\mathbf{E 4}$ & 17.69 & 15.14 & 13.18 & 11.30 & 9.98 \\
\hline \multirow{5}{*}{$\begin{array}{l}\text { Ash } \\
(\%)\end{array}$} & Control & 0.99 & 1.11 & 1.20 & 1.29 & 1.41 \\
\hline & E1 & 1.04 & 1.21 & 1.31 & 1.39 & 1.48 \\
\hline & E2 & 1.14 & 1.26 & 1,31 & 1.41 & 1.51 \\
\hline & $\mathbf{E 3}$ & 1.20 & 1.29 & 1.39 & 1.46 & 1.59 \\
\hline & E4 & 1.99 & 2.01 & 2.17 & 2.29 & 2.36 \\
\hline \multirow{5}{*}{$\begin{array}{c}\text { Fat } \\
(\%)\end{array}$} & Control & 16.39 & 16.03 & 15.20 & 14.09 & 12.99 \\
\hline & E1 & 16.58 & 16.19 & 15.40 & 14.55 & 13.29 \\
\hline & $\mathbf{E 2}$ & 16.73 & 16.30 & 15.99 & 15.10 & 14.06 \\
\hline & E3 & 17.12 & 16.99 & 16.02 & 15.57 & 14.49 \\
\hline & E4 & 18.19 & 17.99 & 17.47 & 16.98 & 16.02 \\
\hline \multirow{5}{*}{$\begin{array}{l}\text { Protein } \\
(\%)\end{array}$} & Control & 11.39 & 11.00 & 10.86 & 9.99 & 9.10 \\
\hline & E1 & 11.58 & 11.19 & 10.99 & 10.42 & 9.99 \\
\hline & E2 & 11.73 & 11.49 & 11.01 & 10.58 & 10.08 \\
\hline & E3 & 11.94 & 11.66 & 11.29 & 10.79 & 10.21 \\
\hline & E4 & 13.19 & 12.99 & 12.10 & 11.57 & 11.01 \\
\hline \multirow{5}{*}{$\begin{array}{l}\text { Crude } \\
\text { fiber } \\
(\%)\end{array}$} & Control & 0.57 & 0.60 & 0.68 & 0.76 & 0.99 \\
\hline & E1 & 0.70 & 0.81 & 0.90 & 0.99 & 1.01 \\
\hline & E2 & 0.83 & 0.99 & 1.01 & 1.11 & 1.24 \\
\hline & E3 & 0.97 & 1.10 & 1.15 & 1.28 & 1.39 \\
\hline & E4 & 1.89 & 1.99 & 2.00 & 2.19 & 2.59 \\
\hline \multirow{5}{*}{$\begin{array}{l}\text { Available } \\
\text { carbohydrate } \\
(\%)\end{array}$} & Control & 46.48 & 47.69 & 50.79 & 53.96 & 58.16 \\
\hline & E1 & 46.59 & 48.90 & 51.65 & 54.10 & 57.23 \\
\hline & E2 & 46.70 & 49.05 & 51.12 & $\mathbf{5 3 . 5 7}$ & 56.67 \\
\hline & E3 & 46.56 & 48.98 & 51.60 & 53.77 & 56.30 \\
\hline & E4 & 47.04 & 49.88 & 53.07 & 55.67 & $\mathbf{5 8 . 0 4}$ \\
\hline
\end{tabular}

E1: $90 \%$ wheat flour $+10 \%$ pearl millet flour

E3: $70 \%$ wheat flour $+30 \%$ pearl millet flour

E2: $80 \%$ wheat flour $+20 \%$ pearl millet flour

E4: $100 \%$ pearl millet flour 
Effect of storage periods at room temperature $\left(25 \pm 1^{\circ} \mathrm{C}\right)$ on microbiological quality of produced cake by replacement wheat flour with pearl millet flour:

The total viable bacterial count is widely used as an indicator microbiological quality of cake. Data in Table (7) showed that on the basis of observations of microbial growth whereby molds have started to grow on the 4th day of storage the pearl millet cake base stored at room temperature, however was seen to be TPC on the 8th day of storage. Based on this study, TPC count increased during storage period of 8 days at room temperature. This happened because the room temperature $\left(25^{\circ} \mathrm{C} \pm 2^{\circ} \mathrm{C}\right)$ is the optimum conditions for growth. These results are in agreement with Chaudhari1 et al. (2017). Temperature that allows growth of microorganism and this temperature also fall below the danger zone temperature which is $4.4-60^{\circ} \mathrm{C}$. Leaving food out too long at room temperature can cause bacteria to grow to dangerous levels that can cause illness because the bacteria grow most rapidly in danger zone temperature, which doubling in number in as little as 20 minutes (United States Department of Agriculture., Food Safety and Inspection Service, 2013).

Table 7. Microbiological quality of produce by cake included replacement wheat flour with pearl millet flour

\begin{tabular}{|c|c|c|c|c|c|}
\hline \multirow{2}{*}{$\begin{array}{l}\begin{array}{l}\text { Storage period } \\
\text { (days) }\end{array} \\
\end{array}$} & \multicolumn{3}{|c|}{ Total bacterial count } & \multirow[b]{2}{*}{$\mathbf{E 3}$} & \multirow[b]{2}{*}{$\mathbf{E 4}$} \\
\hline & Control & E1 & E2 & & \\
\hline $\mathbf{0}$ & ND* & ND* & $\mathrm{ND}^{*}$ & $\mathrm{ND}^{*}$ & $* \mathrm{ND}$ \\
\hline 4 & $9 \times 10$ & $13 \times 10$ & $16 \times 10$ & $20 \times 10$ & $35 \times 10$ \\
\hline 6 & $2 \times 10^{1}$ & $3.2 \times 10^{1}$ & $3.9 \times 10^{1}$ & $4.2 \times 10^{1}$ & $5.1 \times 10^{1}$ \\
\hline 8 & $2.5 \times 10^{2}$ & $3.5 \times 10^{2}$ & $5 \times 10^{2}$ & $5.9 \times 10^{2}$ & $9 \times 10^{2}$ \\
\hline \multicolumn{6}{|l|}{ Molds and yeasts } \\
\hline 0 & Less than 15 & Less than 15 & Less than 15 & Less than 15 & Less than 15 \\
\hline 4 & $15 \times 10$ & $23 \times 10$ & $30 \times 10$ & $33 \times 10$ & $60 \times 10$ \\
\hline 6 & $100 \times 10$ & $2.5 \times 10^{2}$ & $3.4 \times 10^{2}$ & $5.5 \times 10^{2}$ & $10 \times 10^{2}$ \\
\hline 8 & $4.7 \times 10^{2}$ & $5.6 \times 10^{2}$ & $7.5 \times 10^{2}$ & $9 \times 10^{2}$ & $40 \times 10^{2}$ \\
\hline \multicolumn{6}{|l|}{ Coliform group } \\
\hline $\mathbf{0}$ & ND** & $\mathrm{ND}^{* *}$ & $\mathrm{ND}^{* *}$ & $\mathrm{ND} * *$ & ND** \\
\hline 4 & $\mathrm{ND} * *$ & $\mathrm{ND} * *$ & $\mathrm{ND} * *$ & $\mathrm{ND} * *$ & $\mathrm{ND}^{* *}$ \\
\hline 6 & $\mathrm{ND} * *$ & $\mathrm{ND} * *$ & $\mathrm{ND} * *$ & $\mathrm{ND} * *$ & $\mathrm{ND} * *$ \\
\hline 8 & $\mathrm{ND} * *$ & $\mathrm{ND}^{* *}$ & $\mathrm{ND}^{* *}$ & $\mathrm{ND} * *$ & $\mathrm{ND} * *$ \\
\hline
\end{tabular}

ND*: Not detected

4.4.3. Sensory evaluation of produced by cake with replacement wheat flour with pearl millet flour:

Sensory evaluation is important criteria in evaluation cake quality. Data in Table (8) indicated that there are significant differences $(\mathrm{p} \leq 0.05)$ between all samples. The obtained data indicated that the pearl millet flour are giving marked $(\mathrm{p} \leq 0.05)$ improvement in height compared with control sample.

Table 8. Sensory evaluation of produced cake by replacement wheat flour with pearl millet flour.

\begin{tabular}{|c|c|c|c|c|c|c|}
\hline \multirow[t]{2}{*}{ Characteristics } & \multicolumn{6}{|c|}{ Cake blends } \\
\hline & Control & E1 & E2 & E3 & E4 & LSD \\
\hline \multirow[t]{2}{*}{ Appearance } & $8.22 \pm$ & $8.38 \pm$ & $8.61 \pm$ & $7.94 \pm$ & $4.94 \pm$ & 0.6220 \\
\hline & $0.446 a b$ & $0.334 \mathrm{c}$ & $0.230 \mathrm{~b}$ & $0.307 \mathrm{c}$ & $0.673 \mathrm{ac}$ & \\
\hline \multirow[t]{2}{*}{ Drumming } & $9.33 \pm$ & $8.66 \pm$ & $8.83 \pm$ & $8.55 \pm$ & $6.05 \pm$ & 0.5665 \\
\hline & $0.280 \mathrm{~b}$ & $0.213 b$ & $0.202 b$ & $0.258 \mathrm{~b}$ & $0.725 \mathrm{ad}$ & \\
\hline \multirow[t]{2}{*}{ Crust color } & $9.05 \pm$ & $8.72 \pm$ & $8.27 \pm$ & $7.88 \pm$ & $4.94 \pm$ & 0.5140 \\
\hline & $0.235 b$ & $0.239 b$ & $0.239 b$ & $0.332 \mathrm{c}$ & $0.585 \mathrm{~d}$ & \\
\hline \multirow[t]{2}{*}{ Crumb color } & $8.72 \pm$ & $8.33 \pm$ & $8.11 \pm$ & $7.61 \pm$ & $4.94 \pm$ & 0.5295 \\
\hline & $0.277 b$ & $0.242 b$ & $0.254 b$ & $0.344 \mathrm{c}$ & $0.585 \mathrm{~d}$ & \\
\hline \multirow[t]{2}{*}{ Taste } & $8.77 \pm$ & $8.22 \pm$ & $8.83 \pm$ & $8.27 \pm$ & $5.61 \pm$ & 0.5347 \\
\hline & $0.366 \mathrm{c}$ & $0.357 \mathrm{c}$ & $0.245 b$ & $0.350 \mathrm{c}$ & $0.479 \mathrm{ab}$ & \\
\hline \multirow{2}{*}{$\begin{array}{l}\text { Thawing in the } \\
\text { mouth }\end{array}$} & $8.77 \pm$ & $8.50 \pm$ & $8.44 \pm$ & $8.38 \pm$ & $5.77 \pm$ & 0.5852 \\
\hline & $0.318 \mathrm{c}$ & $0.282 b$ & $0.293 b$ & $0.380 \mathrm{c}$ & $0.629 \mathrm{ac}$ & \\
\hline \multirow[t]{2}{*}{ Cohesion } & $9.33 \pm$ & $9.16 \pm$ & $9.05 \pm$ & $8.88 \pm$ & $5.38 \pm$ & 0.5709 \\
\hline & $0.213 b$ & $0.202 b$ & $0.205 b$ & $0.311 \mathrm{c}$ & $0.737 \mathrm{ad}$ & \\
\hline \multirow[t]{2}{*}{ Height } & $9.16 \pm$ & $9.27 \pm$ & $9.50 \pm$ & $9.38 \pm$ & $7.05 \pm$ & 0.4004 \\
\hline & $0.217 \mathrm{~b}$ & $0.157 \mathrm{a}$ & $0.121 \mathrm{a}$ & $0.216 \mathrm{~b}$ & $0.494 \mathrm{ab}$ & \\
\hline
\end{tabular}




\begin{tabular}{lllllll}
\hline Table 8. Cont. & & & & & \\
\hline Texture & $9.33 \pm$ & $9.16 \pm$ & $9.05 \pm$ & $8.94 \pm$ & $6.22 \pm$ & 0.4299 \\
& $0.161 \mathrm{a}$ & $0.145 \mathrm{a}$ & $0.189 \mathrm{a}$ & $0.261 \mathrm{~b}$ & $0.533 \mathrm{~d}$ & \\
Odor & $8.72 \pm$ & $9.11 \pm$ & $8.94 \pm$ & $8.77 \pm$ & $6.88 \pm$ & 0.5144 \\
& $0.441 \mathrm{ab}$ & $0.169 \mathrm{a}$ & $0.189 \mathrm{a}$ & $0.274 \mathrm{~b}$ & $0.529 \mathrm{~d}$ & \\
Overall & $88.61 \pm$ & $88.61 \pm$ & $89.77 \pm$ & $87.61 \pm$ & $62.55 \pm$ & 5.3155 \\
acceptability & $3.593 \mathrm{~cd}$ & $1.896 \mathrm{bd}$ & $1.729 \mathrm{bd}$ & $2.359 \mathrm{ac}$ & $6.452 \mathrm{e}$ & \\
\hline
\end{tabular}

E1: $90 \%$ wheat flour $+10 \%$ pearl millet flour E2: $80 \%$ wheat flour $+20 \%$ pearl millet flour

E3: $70 \%$ wheat flour $+30 \%$ pearl millet flour $\quad$ E4: $100 \%$ pearl millet flour

Effect of replacement wheat flour with pearl millet flour on texture measurement (mechanical properties) of produced during storage period:

Data in Table (9) showed that the replacement of wheat flour with pearl millet flour presented very similar hardness values to each other, even higher than those for the control sample. In these samples the hardness values also increased with storage time, indicated that the crumb develops far less firmness over time and demonstrating the effectiveness of the pearl millet flour in maintaining freshness.

An increase in chewiness was observed in E1 and E3 samples compared with the control sample which indicates a low degree of softness and chewiness is one of the texture parameters easily correlated with sensory evaluation. A gradual increase in hardness according to Ramesh (2014) an increase in cake hardness was reported by Lee et al. (2004) springiness was increased in E2 sample while, it decreased in control sample. A subjective evaluation of springiness is normally made by consumers and consists of slightly pressing the piece of food, by hand or with the mouth, and verifying how easily it returns to the original size.

Regarding springiness change during storage in Table (9) an increase was observed during in $10 \%$ and $30 \%$ pearl millet flour and decrease in $20 \%$ and $100 \%$ pearl millet flour in comparison with the control sample. An increase in chewiness was observed in chitosan chewiness in comparison with the control sample which indicates a low degree of softness and crispness chewiness is one of the texture parameters easily correlated with sensory analysis through trained panels. A gradual increase in hardness observed when replacement wheat flour with pearl millet flour, the pearl millet flour negative effect could be due to the increase in hardness Ramesh (2014) Both, gumminess and chewiness are parameters dependent on hardness. Therefore, their values, both in fresh and storage cakes, followed a similar trend than that of hardness. A subjective evaluation of springiness is normally made by consumers and consists of slightly pressing the piece of food, by hand or with the mouth, and verifying how easily it returns to the original size.

Table 9. Effect of storage period at room temperature $(25 \pm 1 \square \mathrm{C})$ of produced cake by replacement of wheat flour with pearl millet flour on texture measurement (mechanical properties):

\begin{tabular}{|c|c|c|c|c|c|}
\hline \multirow{2}{*}{$\begin{array}{l}\text { Mechanical } \\
\text { properties }\end{array}$} & \multicolumn{5}{|c|}{ Cake blends } \\
\hline & Control & E1 & E2 & E3 & E4 \\
\hline \multicolumn{6}{|l|}{ Zero time } \\
\hline Hardness Cycle 1 & $17.96 \mathrm{~N}$ & $26.53 \mathrm{~N}$ & $22.03 \mathrm{~N}$ & $24.14 \mathrm{~N}$ & $43.46 \mathrm{~N}$ \\
\hline Adhesiveness & $0.70 \mathrm{~mJ}$ & $0.20 \mathrm{~mJ}$ & $0.20 \mathrm{Mj}$ & $0.30 \mathrm{~mJ}$ & $0.90 \mathrm{~mJ}$ \\
\hline Resilience & 0.25 & 0.26 & 0.23 & 0.22 & 0.09 \\
\hline Hardness Cycle 2 & $15.30 \mathrm{~N}$ & $21.78 \mathrm{~N}$ & $18.51 \mathrm{~N}$ & $20.05 \mathrm{~N}$ & $26.44 \mathrm{~N}$ \\
\hline Cohesiveness & 0.61 & 0.55 & 0.52 & 0.55 & 0.22 \\
\hline Springiness & $6.28 \mathrm{~mm}$ & $6.49 \mathrm{~mm}$ & $5.69 \mathrm{~mm}$ & $6.58 \mathrm{~mm}$ & $4.13 \mathrm{~mm}$ \\
\hline Gumminess & $11.02 \mathrm{~N}$ & $14.64 \mathrm{~N}$ & $11.36 \mathrm{~N}$ & $13.29 \mathrm{~N}$ & $9.62 \mathrm{~N}$ \\
\hline Chewiness & $69.20 \mathrm{~mJ}$ & $95.00 \mathrm{~mJ}$ & $64.60 \mathrm{~mJ}$ & $87.40 \mathrm{~mJ}$ & $39.70 \mathrm{~mJ}$ \\
\hline \multicolumn{6}{|l|}{4 Days } \\
\hline Hardness Cycle 1 & $24.62 \mathrm{~N}$ & $35.54 \mathrm{~N}$ & $8.53 \mathrm{~N}$ & $13.62 \mathrm{~N}$ & $15.04 \mathrm{~N}$ \\
\hline Adhesiveness & $0.20 \mathrm{~mJ}$ & $0.20 \mathrm{~mJ}$ & $0.50 \mathrm{~mJ}$ & $1.10 \mathrm{~mJ}$ & $1.80 \mathrm{~mJ}$ \\
\hline Resilience & 0.25 & 0.21 & 0.14 & 0.16 & 0.12 \\
\hline Hardness Cycle 2 & $21.51 \mathrm{~N}$ & $29.05 \mathrm{~N}$ & $6.55 \mathrm{~N}$ & $10.69 \mathrm{~N}$ & $11.20 \mathrm{~N}$ \\
\hline Cohesiveness & 0.57 & 0.50 & 0.38 & 0.39 & 0.32 \\
\hline Springiness & $5.55 \mathrm{~mm}$ & $7.65 \mathrm{~mm}$ & $1.11 \mathrm{~mm}$ & $2,78 \mathrm{~mm}$ & $2.50 \mathrm{~mm}$ \\
\hline Gumminess & $14.13 \mathrm{~N}$ & $17.93 \mathrm{~N}$ & $3.22 \mathrm{~N}$ & $5.26 \mathrm{~N}$ & $4.82 \mathrm{~N}$ \\
\hline Chewiness & $78.40 \mathrm{~mJ}$ & $137.2 \mathrm{~mJ}$ & $3.60 \mathrm{~mJ}$ & $14.60 \mathrm{~mJ}$ & $12.10 \mathrm{~mJ}$ \\
\hline
\end{tabular}

E1: $90 \%$ wheat flour $+10 \%$ pearl millet flour $\mathbf{E 2 :} 80 \%$ wheat flour $+20 \%$ pearl millet flour

E3: $70 \%$ wheat flour $+30 \%$ pearl millet flour $\quad$ E4: $100 \%$ pearl millet flour 


\section{Conclusions}

The supplementation of the pearl millet flour showed a significant improvement each of the properties. Specific height has increased with every treatment, though it the replacement wheat flour with pearl millet flour was a highly effective. Increased protein and fat replacement wheat flour with pearl millet flour add all of the treatments replacement wheat flour with pearl millet flour showed a noticeable positive change in the rheological properties. All of these changes culminated in the sensory evaluation, which showed a significant approbation for replacements compared with the control sample.

\section{References}

A.A.C.C. (2000). American Association for Cereal Chemistry. 10th Edition. AACC International, St. Paul. MN.

A.A.C.C. (2002).Approved Method of American Association of Cereal Chemists, published by American Association of Cereal Chemists, Ins. St.Paul, Minnesota, USA.

A.O.A.C. (2016): Association of Official Analytical Chemists. Official Methods of

Analysis. (20th Ed.) Maryland, USA.

Amigo, J. M.; del Olmo, A.A.; Engelsen, M.M.; Lundkvist, $H$. and Engelsen, S.B.(2016). Staling of white wheat bread crumb and effect of maltogenic $\alpha$-amylas

Part 1: Spatialdistribution and kinetic modeling of hardness and resilience. Food Chemistry, 208: 318-325.

(APHA) American Public Health Association (1992). Compendium of Method for the Microbiological Examination of Food.Washington.

Aprodu, I. and Banu, I. (2014). Rheological, thermo- mechanical, and baking properties of wheat-millet flour blends. Food Science and Technology International, 21: 342353.

Caballero, P.A.; Gomez, M.; and Rosell, C.M.(2007). Improvement of dough rheology, bread quality and bread shelf-life by enzymes combination. Journal of Food Engineering, 81(1) p: 42-53.

Chaudhari1, S.N.; S.B. Palve; K.R. Choudhai; D.H. Pawar and S.S. Gaikwad.

(2017). Microbial Analysis of Cake Base Stored at Room Temperature with out Added Chemical Preservative. Int.J .Curr.Microbiol.App.Sci 6 (12): 35193525 .

Chethan, S. and Malleshi, N. (2007). Finger millet polyphenolds: optimization of extraction and the effect of $\mathrm{pH}$ on their stability. Food Chemistry,105(2), 862-870.
Devi, P.B.; Vijayabharathi, R.; Sathyabama, S.; Malleshi, N.G. and Priyadarisin, V.B. (2011). Health benefits of finger millet polyphenols and dietary fiber: a review. Journal of Food Science and Technology 1-20.

Florence Suma, P.M. (2012). Studies on the nutritional composition, functionality and utilization of pearl millet (Pennisetum typhoideum). Food Science and Nutrition (89).

Gavurnikova, S.; Havrlentova, M.; Mendel, L.; Cicova, I.; Bielikova, M. and Kraic, J. (2011). Parameters of wheat flour, dough, and bread fortified by buckwheat and millet flours. Agricultur (Polnohospodarstvo), 57,144-153.

Goswami, D.; Gupta , S.K.; Mridula, D.; Sharma, M. and Tyagi, S.K. Barnyard millet based muffins: Physical, textural and sensory properties. LWT- Food Science and Technology, 64: 374-380.

Hafez, A.A. (2012). Physico-chemical and sensory properties of cakes supplemented with different concentration of marjoram. Australian Journal of Basic and Applied Sciences, 6(13): 463- 470.

Kahraman; K.; Sakıyan; O.; Ozturk; S.; Koksel; H.; Sumnu; G. and Dubat; A. (2008). Utilization of Mixolab® to predict the suitability of flours in terms of cake quality. European Food Research and Technology, 227(2): 565-570.

Lee, S., Inglett, G. and Carriere, C. (2004). Effect of nutrim oat bran and flaxseed on rheological properties of cakes. Cereal Chemistry, 81(5), 637-642

Levine, D.M.; Berenson, M.L.; and Stephan, D. (1999). Statistics for managers using Microsoft Excel (Vol. 660). Upper Saddle River, NJ: Prentice hall.

Lorenz, K. and Dilsaver, W. (1980). Rheological properties and food applications of proso millet flours. Cereal Chemistry, 57: 21-24.

Maktouf, S.; Jeddou, K.B.; Moulis, C.; Simeon, M.R.; and Ghorbel, R.E.(2016). Evaluation of dough rheological properties and bread texture of pearl millet wheat flour mix. Journal of Food Science and Technology, 1-6.

Pradhan, A.; Nag, S.K. and Patil, S.K. (2010). Dietary management of finger millet control diabetes. Current Science. 98 (6): 763-765.

Rajiv, J.; Soumya, C.; Indrani, D. and Venkateswara, R.G. (2011). Effect of replacement of wheat flour with finger millet flour (Eleusine corcana) on the batter microscopy, rheology and quality characteristics of muffins. Journal of Texture Studies, 42(6): 478-489.

Ramesh, M. (2014). Use of millets for partial wheat replacement in bakery product. Faculty of Agricultural and Environmental Sciences McGill University,167- 173. 
Sharma, B.; Gujral, H.S. and Solah, V. (2017). Effect of incorporating finger millet in wheat flour on Mixolab behavior, chapatti quality and starch digestibility, Food Chemistry, 156-164.

Sharoba, A.M.; Farrag, M.A. and Abd El-Salam, A.M. (2013) Utilization of some fruits and vegetables waste as a source of dietary fiber and its effect on the cake making and its quality attributes. Journal of Agroalimentary Processes and Technologies, 19 (4):429-444

Subba, R.M. and Muralikrishna, G. (2001). Nonstarch polysaccharides and bound phenolic acids from native and malted finger millet. Food Chemistry, 72:187- 92.

United States Department of Agriculture's Food Safety and Inspection Service, (2013). Molds on food: Are they dangerous? Retrieved from

http://www.fsis.usda.gov/wps/wcm/connect/a87c dc2c-6ddd-49f0-bd1f39308674

2e68/Molds_on_Food.pdf?MOD=AJPERES.

United States Food and Drug Administration, (2001). Bacteriological analytical manual online. Retrieved http://www.911emg.

com/Ref\%20Library\%20ERG/FDA\%20

Bacteriological\%20Analysis.pdf.

Wilderjans, E.; Pareyt, B.; Goesaert, H.; Brijs, K. and Delcour, J.A. (2008). The role of gluten in a pound cake system: a model approach based on gluten-starch blends. Food Chemistry, 110(4): 909-915.

Zhang, Y.Y.; Song, Y.; Hu, X. S.; Liao, X. J.; Ni,Y.Y.; and Li, Q. H. (2012). Effects of sugars in batter formula and baking conditions on 5- hydroxyl methyl furfural and furfural formation in sponge cake models. Food Research international, 49(1): 439-445.

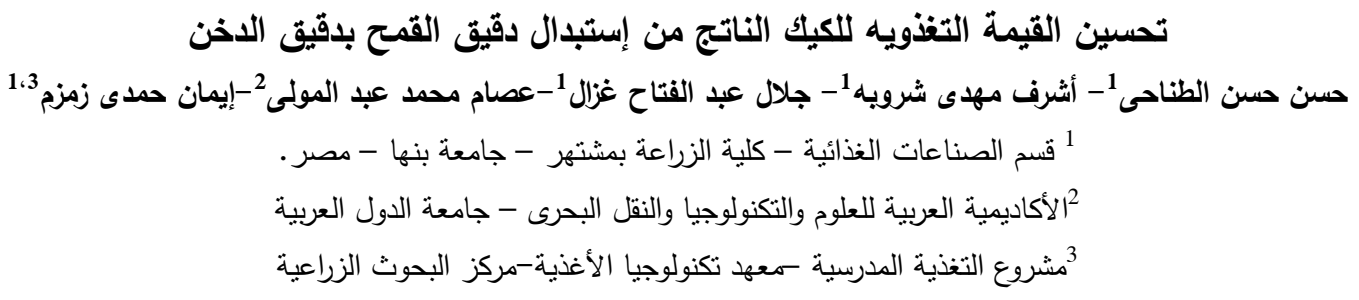

تحتل منتجات المخابز موقع مهم فى تغذية الإنسان محليا وعالميا. ونظرا لوجود فجوة بين الإنتاج والإنتهلاك تلجأ الدوله إلى إستيراد

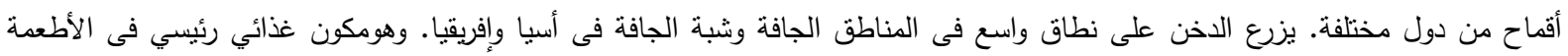

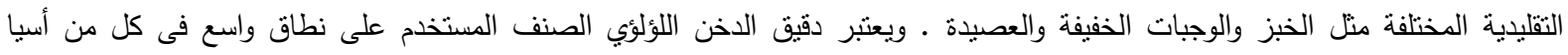

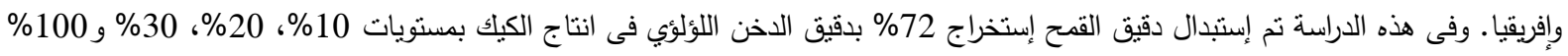

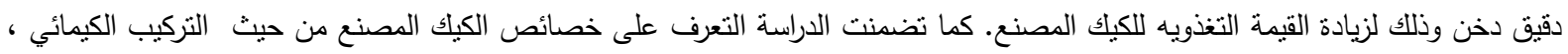

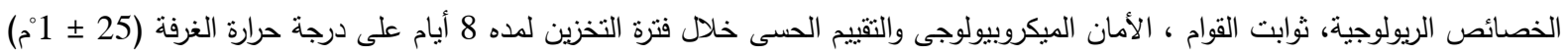

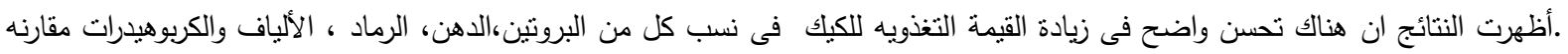

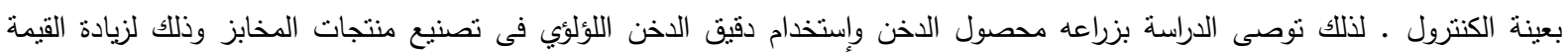
التغذويه لهذه المنتجات.

الكلمات المساعدة: دقيق الذخن - الكيك - الخصائص الريولوجية -ـثابت القوام- التركيب الكيماوى- الأمان الميكروبيولوجى- الصفات الحسية 